PROBLEMS

OF MANAGEMENT IN THE $21^{\text {st }}$ CENTURY Vol. 13, No. 1, 2018

34

\title{
PERSONAL MANAGEMENT CHALLENGES IN GEORGIAN COMMERCIAL BANKS
}

\author{
Nana Shonia \\ Akaki Tsereteli State University, Georgia \\ E-mail: nanashonia@atsu.edu.ge \\ Zurab Mushkudiani \\ Kutaisi City Council, Georgia \\ E-mail: zura_8355@yahoo.com
}

Khatuna Shalamberidze, Natela Janelidze

Akaki Tsereteli State University, Georgia

E-mail: Khatuna.Shalamberidze@atsu.edu.ge, Natela.janelidze@atsu.edu.ge

\begin{abstract}
The aim of the research was to investigate the relation of Personal/Human Resource Management in Commercial Banks in Georgia. The effective, transparent and fair managing depends on many different factors and among them the personal/human resources management is one of the most important factors. The guarantee that the people who are properly chosen in the commercial bank, with appropriate skills, competencies and qualifications significantly increases their job effectiveness. It is remarkable that human resources management is being implemented differently in various countries. In some countries a special agency is created, which is centrally managed by the management of all human resources. While in some countries this practice is completely decentralized and each agency or department individually carries out personnel management. However, mainly mixed practices exist in the country where there is a central agency of human resources management, which defines the general strategy of human resource management, and directly implementing relevant activities such as selection and assessment. The results of the research allowed concluding that the main factor related to personal management in the commercial banks was the shortage of professionalism and financial resources. The lack of qualified staff was mentioned by the managers as an insuperable problem to introduce innovations as well.
\end{abstract}

Keywords: commercial bank, personal managemnet, innovative management, physiological climate.

\section{Introduction}

Human resources represent a combination of persons employed in the organization, people who work individually or in groups to achieve the strategic goals faced by the organization. HR - includes a combination of social and personal psycho-social features (Arthur, 1994). They are characterized as the following:

- People who possess intellect

- Intellectual ownership can continually improve and develop, which is the main source of public and company advancement

- People choose a certain type of activity and have certain goals

The main source of competitiveness of the commercial bank is its staff, they determine the efficiency of the bank's activities, and the managers of the staff perform the main role in the selection and use of the staff. Such an approach increases the interest of the employees and improves the psychological climate in the organization (Baratashvili, Talakvadze, 2010). But this 
form has a negative side - it is difficult to get new, progressive people to work, which negatively

affects the organization's activities.

The main purpose of working with personnel in modern conditions is the formation of a person who possesses high responsibility, psychology of psychology and high qualifications (Beridze, Papuashvili, 2013).

The studies have begun from the second half of the twentieth century to improve corporation's management. At the modern stage, among the scientists in the management of the corporation, different approaches and directions of management regulation have been developed, including the strategic management, the introduction of a corporate management, strategic mechanism, and innovative management, $\mathrm{HR}$ management, which faces up the international standard and ensures the development, sustainability, development strategies and enterprisepractice of the corporation's competitiveness (Batt, Cascio, 1991).

It is considered that economic strategy should be uniform as well as approaches, as business strategic management is the result of development of management creations and is focused on strategic decisions (Beer, Spector, Lawrence, Walton, 1984). The importance of the paper is the importance of the strategic management of the corporation's activity as an important factor in the establishment of corporation and profit growth that requires scientific, theoretical and practical reasoning.

The need for personnel management research also follows from the fact that the results of the research can be used as a determining indicator of the commercial bank's economic policy. Strategic management, as an important instrument of management of the company, has undertaken several phases of development and laid the foundation for scientific research into independent directions such as investment management, risk management, company HR management (Berthel, Becker, 2017).

An important aspect of effective banking management is personnel management. The management of personnel in the commercial bank of Georgia is very specific and is due to the peculiarities of banking activities themselves. The aim of the Bank is to achieve its objectives and to realize its mission through effective utilization of available resources (Cappelli, Neumark, 2001). The effective use of resources in the context of HR management means ensuring that each employee manages to showcase their capabilities, competencies and performs the duties in the quality. The bank staff requires professionalism, skills and personal qualities. It is also added that the bank's staff is not only responsible for the functionality of its functions but also the neighboring and non-conventional colleagues, which is due to the fact that the commercial bank is a very difficult business and it works in a very diverse profession.

The success of the commercial bank depends on people working there as human resources. We can divide issues related to human resources in four categories:

- Acceptance of personnel and staff selection

- Salary and working conditions

- Training and professional development

- Proactive and productive

\section{Literature Review}

The human resource is critical and difficult to manage. It is because human behavior is highly unpredictable. It differs not only from individual to individual, but often on the part of the same individual at different points of time (Deepak, Jame, Patrick, 2003). In spite of biological and cultural similarities, human beings do not only differ in their appearance, but also in their capabilities based on their background, training and experience. Human resource or a person at work is the most important component of the undertaking (Delery, 1998. Drucker, 2011). Management cannot afford to ignore human resource at any cost. Management is the 
Nana SHONIA, Zurab MUSHKUDIANI, Khatuna SHALAMBERIDZE, Natela JANELIDZE. Personal management challenges in Georgian commercial banks

PROBLEMS

OF MANAGEMENT

IN THE $21^{\text {st }}$ CENTURY Vol. 13, No. 1, 2018

36 process of efficiently getting activities completed with and through other people. The management process includes planning. Organizing, leading and controlling activities take place to accomplish objectives. Being a branch of management, personnel management also performs the same functions towards the 22 achievements of objectives. Different terms are used for personnel management (Dunlop, Weil, 1996). The different terms are labor management, labor administration, labor management relations, employee employer relations, personnel administration, human asset management, human resources management etc. In simple sense, human resource management means employing people, developing them, utilizing, compensating and maintaining their services in tune with the job and organizational requirements (Table 1).

The principal component of an organization is its human resources or 'People at work'. Human resources have been defined from the national point of view as, "the knowledge, skills, creative abilities, talents and aptitudes obtained in the population (Gechbaia, Mushkudiani, Shonia, 2018). whereas from the viewpoint of the individual enterprise, they represent the total of the inherent abilities, acquired knowledge and skills as exemplified in the talents and aptitudes of its employees". Cascio calls these resources 'human factors' which refer to "a whole consisting of inter-related, inter-dependent and interacting physiological, psychological and ethical components.

Table 1. Principles of management, staff selection system.

\begin{tabular}{ll}
\hline Principle name & Principle context \\
\hline Complexity & $\begin{array}{l}\text { When forming a personnel management system it is important to take into account all } \\
\text { factors affecting the management system and to include staff. }\end{array}$ \\
\hline Operational & $\begin{array}{l}\text { Decision making of decisions for analysis and improvement of personnel manage- } \\
\text { ment system to prevent complications and complications }\end{array}$ \\
\hline Simplicity & $\begin{array}{l}\text { The easier the personnel management system, the better it works. Of course, this } \\
\text { does not exclude the simplification of the personnel management system for the dam- } \\
\text { age of the Copenhagen. }\end{array}$ \\
\hline Hierarchy & $\begin{array}{l}\text { The personnel management system should provide hierarchical interdependence } \\
\text { between separate parts of management, the principal characteristic of which is the }\end{array}$ \\
\hline asymmetric transmission of information in the "down" and "top" management system. \\
\hline Selection and distribution
\end{tabular}

(Source: National Bank of Georgia, 2018) 
Nana SHONIA, Zurab MUSHKUDIANI, Khatuna SHALAMBERIDZE, Natela JANELIDZE. Personal management challenges in Georgian commercial banks

Commercial banks are private financial institutions, which primary objective is to serve as financial regulatory body in handling issues preferably on finances and personal management. The researcher is of the view that all over the world every organization be it private or public, must be managed by rules and regulations, but the major issue here is whether the rules managing the appointment of staff strictly adhere to or not. Banks may renew their personal management strategies in a number of ways, which undoubtedly reflects, bank's strong performance.

\section{Methodology of Research}

\section{General Background}

Methodological innovations are mainly emphasized in the banking sector, which are supplements to a service, related with development of ideas and organizational structures. Within the framework of the research, the authors want to receive answers to the questions: what form of innovations is introduced most frequently by the commercial banks and what factors influence the introduction of innovation in the service in banks? Managers of commercial banks were inquired within the framework of the research to obtain data about the innovation of service in commercial banks and the impacting factors in the introduction of innovations. The inquiry took place from July 15 to September 10, 2017. To obtain data, a quantitative type of survey was conducted using the questionnaire technique of data collection. The banks were selected only for the given research and their composition is random. The questionnaire respected the ethical aspect and anonymity of respondents. A total of 500 randomly selected banks took part in the survey. They were contacted by a face-to-face structured interview. The questionnaire survey was completed by persons responsible for human resources in an organization, mostly by CEO or HR department director.

\section{Table 2. Research instrument - questionnaire.}

\begin{tabular}{|c|c|}
\hline Code & Questions \\
\hline Q1 & $\begin{array}{l}\text { What is your relationship with the bank } \\
\text { a. I work b. I was working c. I got internships d. No relationship }\end{array}$ \\
\hline Q2 & $\begin{array}{l}\text { What is your level of education? } \\
\text { a. Bachelor b. Master c. High School }\end{array}$ \\
\hline Q3 & $\begin{array}{l}\text { Your basic specialty } \\
\text { a. Economics b. Business c. Humanitarian d. Technical }\end{array}$ \\
\hline Q4 & $\begin{array}{l}\text { What are the basic criteria for employees in commercial banks? } \\
\text { a. Professionalism; b. Higher education (any); c. Recommendations; d. Other }\end{array}$ \\
\hline Q5 & $\begin{array}{l}\text { Does the Bank provide its own staff and professional growth? } \\
\text { a. Yes b. No }\end{array}$ \\
\hline Q6 & What methods of motivation are using the Bank for encouraging co-workers? \\
\hline Q7 & $\begin{array}{l}\text { Is internship program paid? } \\
\text { a. Yes b. No }\end{array}$ \\
\hline Q8 & $\begin{array}{l}\text { What is the main reason for the dismissal of the co-workers? } \\
\text { A. Low level of qualification; B. Restructuring; C. Wish to get new D. Other }\end{array}$ \\
\hline Q9 & Why is the bank receiving staff of another profession? \\
\hline Q10 & Why do not you receive professional staff at the appropriate level? \\
\hline Q11 & $\begin{array}{l}\text { What is the working environment? } \\
\text { A. Tough b. Liberal G. Friendly }\end{array}$ \\
\hline
\end{tabular}


Nana SHONIA, Zurab MUSHKUDIANI, Khatuna SHALAMBERIDZE, Natela JANELIDZE. Personal management challenges in Georgian commercial banks

OF MAN

AGEMENT

IN THE $21^{\text {st }}$ CENTURY Vol. 13, No. 1, 2018

38

\section{Data Analysis}

In official quantitative research, the data collection was conducted using intervieweradministered. The interviewees were from banks and financial institutions. A stratified sampling technique was used to generate a sample based on types of personal management in commercial banks. The specific survey structure is as follows.

Table 3. Interview sample structure based on types of personal management commercial bank

\begin{tabular}{|c|c|c|c|c|}
\hline & Number & Number & & \\
\hline \multirow{3}{*}{ Criteria } & of banks/ & of people & Number of & Interviewee \\
\hline & Financial & expected & \multirow[t]{2}{*}{ valid votes } & \multirow[t]{2}{*}{ structure } \\
\hline & I institutions & to interview & & \\
\hline Professional growth & 16 & 8 & 8 & $3.80 \%$ \\
\hline Basic specialist & 88 & 44 & 42 & $20.10 \%$ \\
\hline Education level in Banks & 153 & 76 & 74 & $35.40 \%$ \\
\hline Relations services with banks & 132 & 66 & 65 & $31.10 \%$ \\
\hline & 17 & 8 & 8 & $3.80 \%$ \\
\hline Working environment at bank & & & & \\
\hline $\begin{array}{l}\text { Basic criteria for employees in commercial } \\
\text { banks }\end{array}$ & 25 & 12 & 12 & $5.70 \%$ \\
\hline Total & 431 & 214 & 209 & $100 \%$ \\
\hline
\end{tabular}

Data processing: Factor analysis method (EFA) and the regression analysis method were used to analyze the data. Finally, we conducted in-depth interviews with 6 bank managers.

\section{Results of Research}

The survey was conducted in several commercial banks in Georgia (TBC Bank, Liberty Bank, VTB Bank, Credo Bank) while talking to the managers and employees of the Bank, as well as former employees. Based on this research, we can define managers' approach and position towards staff (on their appointment and dismissal), as well as the personnel feedback on the recruitment, retraining and release of staff. 
Nana SHONIA, Zurab MUSHKUDIANI, Khatuna SHALAMBERIDZE, Natela JANELIDZE. Personal management challenges in Georgian commercial banks

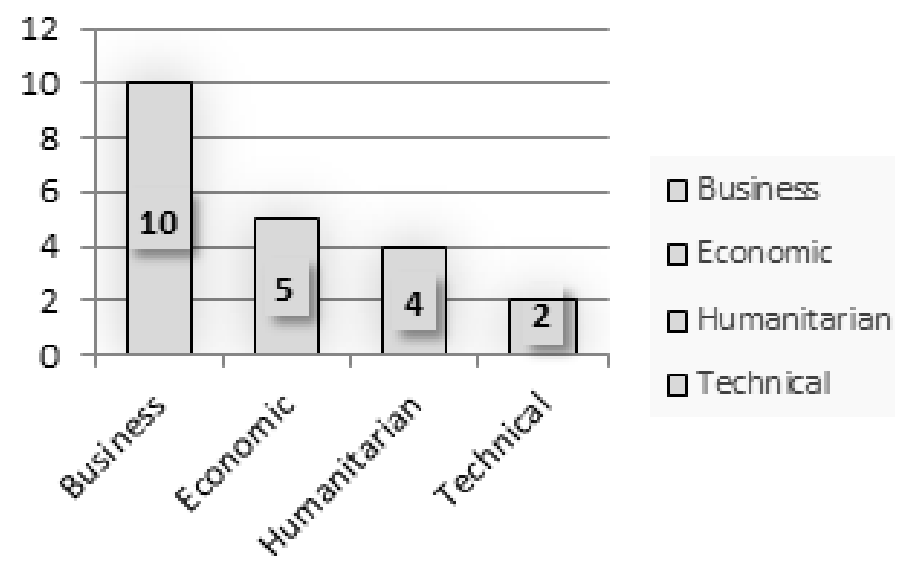

Figure 1. The staffs' education operating in Georgian banks according to the specialty.

The results attest that $48 \%$ of employees in the bank are business administration specialists, while the remaining $52 \%$ are employees with economic, humanitarian and technical education (Figure 1).

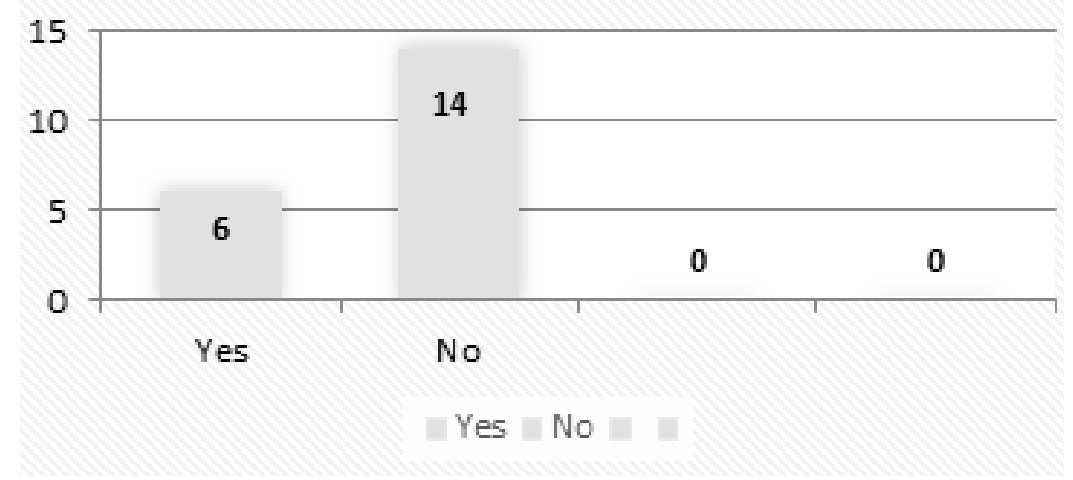

Figure 2. Internship program in commercial banks.

The research has shown, in some issues, such as receiving, retraining, reimbursement or retrenchment of interns, opinions between managers and employees, which is surprisingly strange, because one of the issues in our research was the internship, we received a response from the managers is paid, the staff at the reception is carried out in a certain post in Turkey, but the majority of the employees said that the internship is not paid, the position of the previous stage in the course of the internship, which has not been paid (Figure 2). 
Nana SHONIA, Zurab MUSHKUDIANI, Khatuna SHALAMBERIDZE, Natela JANELIDZE. Personal management challenges in Georgian commercial banks

OF MANAGEMEN'T IN THE $21^{\text {st }}$ CENTURY Vol. 13 , No. 1,2018

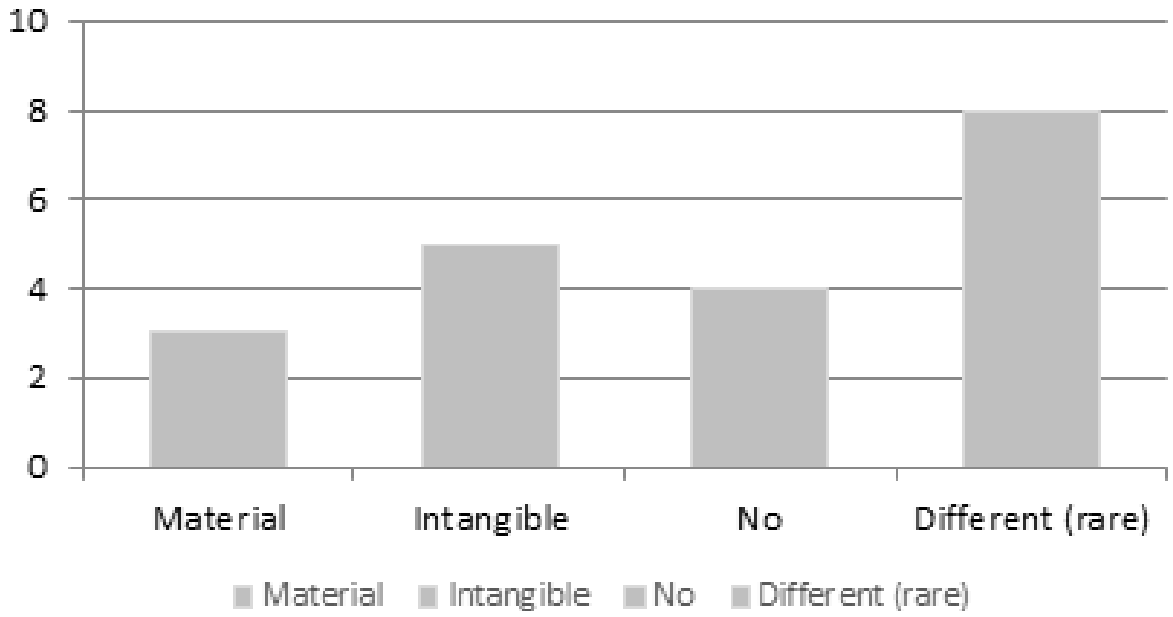

Figure 3. Motivation methods.

The views and responses to the motivation and encouragement were also the main points of discussion, and the managers noted that there are plenty of encouraging means for motivation, such as: thankfulness diploma, monetary stimulation, bonuses, new year gifts, lottery, promotions. Those named methods were mentioned by the majority interviewed people, but also noted that most of those methods are the theory of motivation and encouragement, but in practice such endorsements received less (Figure 3).

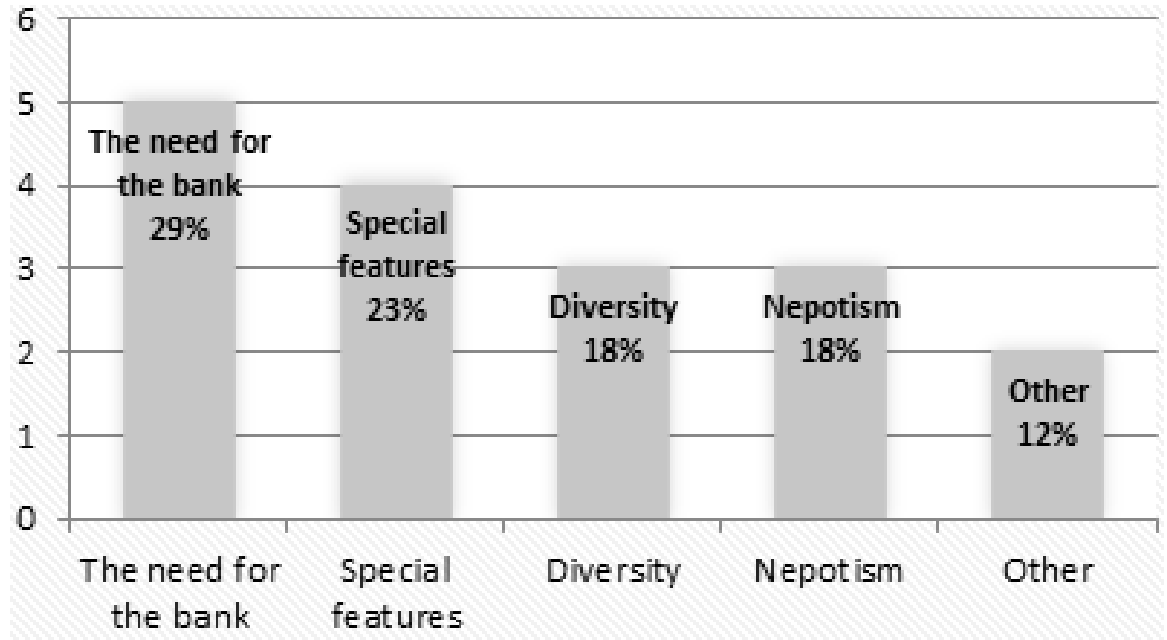

Figure 4. Reasons for receiving other professions.

The results of the research show that $29 \%$ of the questioned have response about the needs of the bank, $23 \%$ talked about special features, $18 \%$ - nepotism and diversity, $12 \%$ - other. The question "why does the bank take the staff of another profession and why not the professional staff of the relevant amount of money?" These are the two questions that we really received from the managers and from the personnel of the bank. Some have pointed out that some "low" positions do not necessarily require a professional employee, and it is also suggested that the bank is working because of the profession of other professions that everyone does not want to work on their own (Figure 4). 

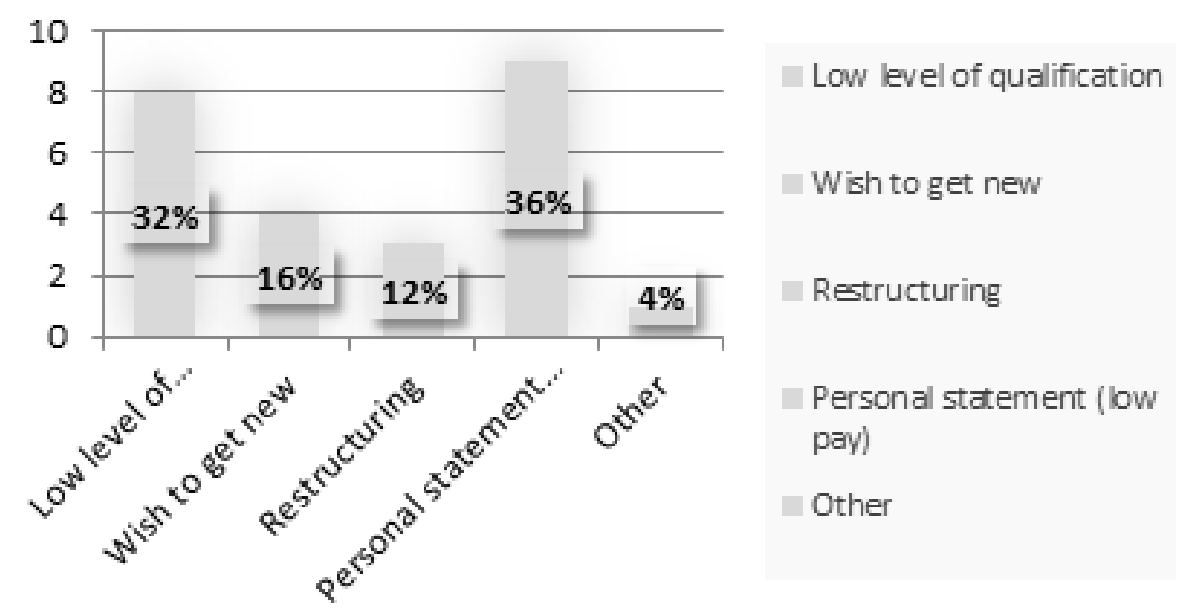

Figure 5. Reasons for dismissal of employees.

There was a different opinion about the dismissal of employees. As one of the bank managers answered my personal desire (the basis of personal statement), but it was interesting to answer the staff itself because they noted that the reasons for the dismissal (leaving the job) are a lot and one of the foremost is the low pay, It was also said that the reason for the release was that the bank is willing to get new and when you investigate why the bank did not recover the cost of preparing a new staff, when an experienced employer was told, one of the respondents replied with a new broom (Figure 5).

\section{Discussion}

The research reviews the critical functions of human resources management. Planning, attracting and selecting staff, their socialization in a commercial bank, as well as job management and bank withdrawal - these are the issues that make it difficult to manage normal personnel policies in banks. Naturally, as a result of reviewed topics in the work, it is impossible to achieve substantial and radical improvement in terms of human resource management, but one thing is definitely achieved and partially achieved - to start talking about human resources management problems and to share the foreign experience in solving this problem.

The research addressed the problems of commercial human resource management and at least some of the problems are: Attracting employees, taking, remuneration system, work schedule, stimulation methods, free internships, departure / dismissal, monitoring. From the point of view, it was thought that the employee of the commercial bank operating in Georgia is adopted by nepotism. Also new and inexperienced personnel are taken to low positions without paying for the internship program.

In terms of insolvency systems we can take an example of some banks (TBC Bank, Liberty Bank, Credo Bank). But it should be noted here that the system of payment in modern commercial banks is mostly similar. For low-level employees only the initial control system (e.g. sales and installment managers, cashier-operators). As for the middle level employers have a slightly different position, I mean that they include introduction, working experience, initial rate control and dual wage system (Loan Officer, Controller, IT Support Administrator).

\section{Conclusions}

In general as research has demonstrated the methods and methods of stimulation and information in personnel management methods, since positive "impacts" (whether bonuses, cash 
Nana SHONIA, Zurab MUSHKUDIANI, Khatuna SHALAMBERIDZE, Natela JANELIDZE. Personal management challenges in Georgian commercial banks

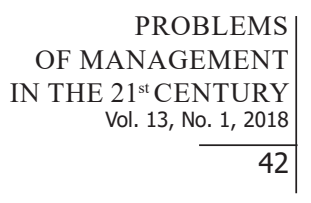

2

incentives, or motivation) are more effective than compulsory sanctions and administrative penalties (reprimand, Privileges come down, release), as it is possible that coercive methods affect employee "human nature" and instead of the error correction and error, staff may seek sanctions or fear reduction and avoidance methods.

The main objective of human resources management is to utilize the human resources in a most optimal manner so that targets can be achieved very effectively and efficiently. For this purpose managing performance of employees as a whole is very important. Performance management takes care of this function, maintains, develops and motivates the people at work to give better results. In the present competitive situation the organization that gives better results can survive, stabilize, grow and excel in the performance.

\section{References}

Arthur, J. B. (1994). Effects of human resources systems on manufacturing performance and turnover. The Academy of Management Journal, 37 (3), 670-687.

Baratashvili, E., Talakvadze, L. (2010). Principles of management. Tbilisi, Georgia.

Beridze, R. (2009). Banking management. Tbilisi, Georgia.

Batt, R. (2004). Who benefits from teams? Comparing the outcomes for managers, supervisors, and workers. Industrial Relations, 43 (1), 183-213. https://doi.org/10.1111/j.0019-8676.2004.00323.x.

Berthel, J. F., Becker, G. (2017). Personal Management. Stuttgart, Germany.

Cappelli, P., Neumark, D. (2001). Do high-Performance work practices improve establishment level outcomes. Industrial and Labor Relations Review, 54 (4), 737-75.

Cascio, W. F. (1991). Costing human resource: The financial impact of behavior in organization. PWSKent, Boston.

Datta, K. D., Guthrie, J. P., Wright, M. P. (2003). MW HRM and firm productivity: Does industry matter? National Academy of Management Meetings, Seattle, WA. Retrieved from https://digitalcommons. ilr.cornell.edu/cgi/viewcontent.cgi?referer=https://www.google.lt $/ \&$ httpsredir $=1 \&$ article $=1024 \&$ context $=$ cahrswp.

Delery, J. E. (1998). Issues of fit in strategic human resource management: Implications for research. Human Resource Management Review, 8 (3), 208-309.

Drucker, P. F. (2011). Management challenges for the 21st Century. New York, USA, 20-40.

Dunlop, J. T., Weil, D. (1996). Diffusion and performance of modular production in the U.S. apparel industry. Industrial Relations, 35 (3), 334-355.

Gechbaia, B., Mushkudiani, Z., Shonia, N. (2018). The modern trends of improvement employee motivation and its impact on their performance management in Georgian reality. International Journal of Current Advanced Research, 7 (3), 10743-10745. Retrieved from http://www. journalijcar.org/sites/default/files/issue-files/5924-A-2018.pdf.

Papuashvili, D. (2013). The effective management of business continuity. Economics and Banking, 3 (2), 23-37. 
Nana SHONIA, Zurab MUSHKUDIANI, Khatuna SHALAMBERIDZE, Natela JANELIDZE. Personal management challenges in Georgian commercial banks

PROBLEMS

OF MANAGEMENT

IN THE $21^{\text {st }}$ CENTURY

Vol. 13, No. 1, 2018

43

Received: March 19, 2018

Accepted: June 29, 2018

Nana Shonia

Doctor of Economics, Professor, Akaki Tsereteli State University, Kutaisi, Georgia.

E-mail: nanashonia@atsu.edu.ge

Zurab Mushkudiani

PR Specialist, Kutaisi City Council, Kutaisi, Georgia.

E-mail: zura_8355@yahoo.com

Khatuna Shalamberidze Doctor of Economics, Associate Professor, Akaki Tsereteli State University, Kutaisi, Georgia.

E-mail: Khatuna.Shalamberidze@atsu.edu.ge

Natela Janelidze

Doctor of Economics, Assistant Professor, Akaki Tsereteli State University, Kutaisi, Georgia.

E-mail: Natela.janelidze@atsu.edu.ge 